\title{
Interpretation Reconsidered: The Definitional Progression in the Study of Esotericism as a Case in Point for the Varifocal Theory of Interpretation
}

\author{
Dimitry Okropiridze
}

This chapter sets out to explore and resolve a philosophical problem, which is at the core of each and every act of interpretation, no matter the subject. Scholarship on esotericism will serve as a case study for the conundrum of opposing interpretations, which-regardless of the intellectual effort-cannot be squared due to their incommensurability and cannot be applied adequately due to their individual necessity. Once the simultaneous incommensurability and individual necessity of the interpretational directionalities in question is understood, a philosophically coherent outline of their side-by-side application emerges, helping the study of esotericism - and by extension the study of any given entity - to a clearer and broader comprehension of the respective subject of inquiry.

The first segment starts out with the definitional progression in the study of esotericism, by selecting the approaches advanced by Antoine Faivre, Wouter Hanegraaff, Michael Bergunder, and Egil Asprem. The argument made here consists in the observation that interpretations of esotericism fall into two categories; one assumes that our interpretation results from esotericism showing itself to the interpreter while the other suggests that our interpretations are socially negotiated projections. The second segment argues that these two fundamental modes of interpretation can be thought of as fundamentally irreconcilable directionalities of interpretation. The implication is that the incommensurability at the core of the interpretational endeavor must be understood philosophically in order to arrive at a clear understanding of esotericism. The third segment explores the rationale behind the simultaneously incommensurable and individually necessary directionalities of interpretation, emphasizing the need to reject attempts of forcibly synthesizing both approaches as the fusion of one with the other is logically impossible, leading to contradictions and a fragmentary appreciation of the interpreted subject. The fourth segment provides a philosophically reflected theory of interpretation, which refrains from a hierarchical ordering of the two incommensurable directionalities, allowing for an analysis of esotericism that continuously oscillates between one and the other option, in order to arrive at an optimal understanding of the subject. The fifth and last segment summarizes the argument and offers 
a perspective on the broader application of the established theory of interpretation.

\title{
1 \\ The Definitional Progression in the Study of Esotericism ${ }^{1}$
}

The quest for the ontological substance of esotericism amidst the epistemological uncertainties of history took place through the assumption that signifiers (i.e., entities that indicate meaning) such as "esotericism" possessed epistemologically accessible signifieds (i.e., the expressed sense): whatever esotericism was, would show itself to the interpreter, once closely examined. Even scholars acknowledging the semantic fluidity of esotericism's signified expected to find specific and enumerable qualities belonging to the phenomenon in question. In his unambiguously titled monograph Access to Western Esotericism (1994) the pioneering scholar Antoine Faivre cautioned against essentialist assumptions about esotericism:

\begin{abstract}
Above all, we do not want to start with what "esotericism" would be "in itself," we doubt that such a thing exists. Nor is it even a domain in the sense we would use in speaking of the domain of painting, philosophy, or chemistry. Rather than a specific genre, it [i.e., esotericism, D.o.] is a form of thought, the nature of which we have to try and capture on the basis of the currents which exemplify it. (Faivre, 1994, p. 4)
\end{abstract}

A philosophically informed glance at Faivre's displacement of esotericism from a "thing in itself" to a "form of thought" reveals it to be a distinction without a difference, ${ }^{2}$ since Faivre did precisely what he set out to avoid: laying claim to the ontology (i.e., the "nature") of esotericism (i.e., "a form of

1 As it is impossible to discuss the entirety of approaches to esotericism on these pages, a number of prominent articulations are selected, in order to set up the ensuing philosophical argument. This does not suggest that the selected approaches can provide a definitive summary of the many academic perspectives on esotericism. Nor does it imply that the approaches discussed here should be reduced to the presented and analyzed material, as the perspective of the authors has continued to evolve throughout their scholarship. This chapter deliberately drops the term "Western" from the often-used notion of "Western esotericism," following the argument advanced by Julian Strube, 2021.

2 Given the (post)Kantian notions of "thing in itself" and "form of thought," Faivre's displacement can be read as an attempt to de-ontologize esotericism and render it an epistemological framework, thereby echoing the narrativizing and discursive approaches. However, as will be argued here, there is no such thing in human interpretation as epistemology without ontological implications and vice versa. Moreover, one does not have priority over the 
thought"). This presupposition of an observer-independent reality "out there," making itself epistemologically available to the interpreter, becomes even more apparent in Faivre's emphasis that through the careful study of the material pertaining to esotericism "[...] we see harmonies and contrasts appear before us" (Faivre, 1994, p. 3). Faivre structured said harmonies and contrasts by attributing to them more or less fixed terminological associations-e.g., gnosis, theosophy, secrecy, occultism, Hermeticism (Faivre, 1994, pp. 19-35) - and debating esotericism in terms of socio-historical (e.g., antiquity, the Middle Ages, the Renaissance etc.) contexts (Faivre, 1994).

The post-Faivre development of an ever more nuanced history of esotericism, tended to move away from essentializing esotericism, instead aiming at narrativizing definitions (i.e., looking at esotericism as appearing in and shaped through linguistic/textual practices). Wouter Hanegraaff suggested that the discourse on "ancient wisdom" in the Renaissance brought about a grand narrative, challenging long-established ideas about the relation between "philosophy and theology, or rationality and revelation" (2012, p. 6). Hanegraaff went on to point out that:

this grand narrative of "ancient wisdom" survived as a widespread but officially discredited countercurrent at odds with mainstream intellectual thought. It has been accepted or implied, in one version or another, by most of the authors and practitioners studied under the umbrella of Western esotericism, up to the present; but, interestingly, it has also strongly influenced the thinking even of the most important modern scholars who have shaped and developed that field. (2012, pp. 6-7)

If, as Hanegraaff seems to imply here, esotericism should be regarded not as a self-sufficient ontological entity, but as a historical web of linguistic/textual negotiations debating the relation between "philosophy and theology, or rationality and revelation", the ontological status of the negotiated subjects (i.e., philosophy, theology/rationality, revelation) must be clarified. On the one hand, Hanegraaff's reifying usage of these signifiers suggests that they can be regarded as self-sufficient ontological entities offering themselves to be "figured out" through various narratives (e.g., "this grand narrative of 'ancient wisdom"” vs. "mainstream intellectual thought"). On the other hand, Hanegraaff's theoretical practice (i.e., his lack of essentialist definitions and the

other, since what is epistemological implies an ontology and what is ontological requires epistemology. 
tendency to treat every subject as a narrative) suggests that philosophy and theology/rationality and revelation are equally to be seen as narratives, which would render esotericism a negotiated narrative about negotiated narratives. Consequently, the narrativizing approach leaves the scholar with the study of competing stories, excluding us from studying reality outside of its emergence in the socio-historically dominant paradigm (Kuhn, 1962); not esotericism, but the discursive formation of what esotericism came to mean and continues to become would then constitute our subject of inquiry. Although this line of thought would constitute a coherent and significant departure from the essentialist impetus visible in Faivre, Hanegraaff is reluctant to deny the agency of his source materials:

In other words, I am not interested in selecting from my materials only the supposedly "esoteric elements" (whatever those might be) but in studying the full complexity of sources that can be seen as falling under the umbrella of "Western esotericism." Yet another way of saying this is that I want to begin with an attitude of listening to whatever my sources want to tell me, rather than an attitude of telling them what they can and cannot talk about. (Hanegraaff, 2013, p. 255)

Here, Hanegraaff reveals a crucial inconsistency: on the one hand, he rejects an essentialist understanding of esotericism ("supposedly 'esoteric elements"), which suggests a narrative character of what is deemed to belong to esotericism. On the other hand, he trusts his sources to inform him about the elements "falling under the umbrella of 'Western esotericism," thereby making his way back to an essentialist notion.

The displacement emerging from Faivre's to Hanegraaff's understanding of esotericism-i.e., the fragmentary shift from the hope for the ontology of esotericism to make itself epistemologically available to the assumption of the epistemological manufacturing of esotericism's ontology — was taken to the next level by the poststructuralist variety of the linguistic turn: the latter declared any articulation about any given entity based on the presupposed "essence" of said entity to be the product of historically and geographically contingent meaning negotiations, rather than descriptions of an extra-discursive reality (Foucault, 1977). Consequently, Michael Bergunder has opted to regard "esotericism" as a discursive entity, the processuality of which can be traced in time and space. Bergunder argued with strong recourse to the philosophy and political thought of Ernesto Laclau that the formation of a more or less stable signified attached to the signifier "esotericism"-e.g., Faivre's placing of esotericism in gnosis, theosophy, and secrecy—takes place 
through articulatory chains emphasizing equivalence (i.e., similarity among elements) and difference (i.e., dissimilarity between elements) (Bergunder, 2010, pp. 20-22). Following the semiotic understanding of Laclau (2005), the given discursive environment can be regarded as the social context in which "esotericism" is understood to be present in elements p, q, r-for instance in "gnosis," "theosophy," "secrecy" - and absent from x, y, z-for instance, "scientific materialism," "religious fundamentalism," "institutionalized religion." ${ }^{3}$ Through asymmetric, i.e., hegemony-aspiring processes of negotiation with competing individuals, collectives, and institutions and always temporary "winners" and "losers" of the negotiated outcome, the signified-e.g., the accepted notion of "esotericism" - is established, subverted, and re-established in an ever-conflictual field of rivaling ascriptions (Bergunder, 2010, pp. 20-22). Hinting at the thoroughly, if not exclusively historicizing dimension of scholarship implied by the discursive approach, Bergunder suggested highlighting the role of hegemonic constellations for the formations of esotericism:

esotericism can be understood as a general term of identification in the form of an empty signifier, which is articulated and reproduced by means of a discourse community and in different fields of discourse. In this sense, esotericism is a historical phenomenon and is to be understood neither as nominalistic nor idealistic, but as a contingent nodal point or rather as the fixing of a contentious power discourse. (2010, p. 26)

While it seems plausible to regard esotericism as a "term of identification," Bergunder's approach begs the question as to how to regard (and whether to trust) his own theoretical tools. After all, terms such as "discourse," "empty signifier," and "power" might be terms of identification of their own, which would make them "the fixing of a contentious power discourse" in their own right. But in that case, Bergunder would be basing his approach to esotericism on something just as discursive and unstable as esotericism itself. If, on the other hand, "discourse," "empty signifiers," and "power" are located beyond the discursive ambit, it is unclear how their ontological status can be substantiated by the discursive approach itself, which must, according to its own presupposition, regard claims to truth as the result of contingent socio-historical negotiations.

Looking back at the progression from Faivre to Hanegraaff to Bergunder, three effects have originated as a result of the repositioning from the attempt

3 The significatory examples given for $\mathrm{x}, \mathrm{y}, \mathrm{z}$ as the chain constituting "non-esotericism" are my own suggestions, based on the discursive gravitation surrounding the signifier "esotericism." Cf. Hanegraaff, 2012. 
to directly access esotericism's ontology to the view of historically changing epistemologies as "production sites" of esotericism. First, the object of study has ceased to be defined by the respective scholar's fiat and/or informed by hegemonic interpretations, often of orientalist and theological provenance, making the latter part and parcel of the critical analysis of esotericism's history as a subset of genealogical approaches (King, 1999; Masuzawa, 2005; McCutcheon, 1997). Second, the now fully semanticized subject of investigation has been thoroughly dematerialized and disembodied: material and somatic elements historically associated with esotericism such as altered states of consciousness, the immersion into archetypal mythologies, and alchemical practices (Hanegraaff, 2012), have been cut back to their emergence as entities within discourse. Third, the rejection of an extra-discursive ontology and its replacement with the epistemology of discourse has effectively reified poststructuralist linguistics as the sole locus of a philosophically idealist ontology (i.e., the notion that discourse generates reality and does not reflect it), ${ }^{4}$ denying or at the very least ignoring the independent legitimacy of scholarship stemming from the natural sciences (which suggest that scientific discourse describes reality rather than creating it) (cf. Boyer, 2001).

As a response to the definitional progression in the study of esotericism leading from the search for esotericism's signified to the historical tracing of its signification, Egil Asprem (2016) has suggested the building block approach as an integration of differing perspectives. Asprem employs the cognitive science of religion as a theoretical framework, which enables the scholar to study the (often scholarly) ascriptions to esotericism-e.g., "the production and dissemination of 'special knowledge" (Asprem, 2016, p. 159) -in a research process that employs "constructionist and naturalistic methods" (ibid., p. 162).

First, ascriptions to esotericism (seen as a "complex cultural concept"; ibid., p. 16o) are identified and disassembled on the level of discourse, where the socially produced semantic constructions of esotericism are analyzed:

These include theological and worldview positions that deny a strict separation of god and world (e.g., cosmotheism, panentheism), notions of an ageless wisdom that can be comprehended with special hermeneutic strategies, and epistemological attitudes emphasizing radical experiential knowledge (e.g., "gnosis"). (ibid., 167)

4 The poststructuralist connection to idealist philosophy is visible in the reception of the (post-)Kantian privileging of epistemology as the basis for philosophizing, acting as a "watchdog" against unwanted ontological intrusions. Cf. Bergunder, 2010. 
Second, the cognitive building blocks pertaining to the practices (e.g., alchemy, astrology, divination, etc.), which are discursively negotiated as esotericism, are broken down to their lower level features, accessible to the cognitive study of religion. For instance, Asprem distinguishes two types of building blocks for the cluster of ascriptions in which esotericism appears as a form of thought or mentality:

universal cognitive dispositions and dispositions of personality and individual difference-which are, moreover, developed, calibrated, and combined in various ways through what we might call learning dispositions. (2016, p. 177)

In a last step, the building blocks associated with the discourse on esotericism are dialectically synthesized with the latter:

Finally, the constructive reassembly stage is where we develop new theory and design research programs that reconnect the lower levels with the cultural and set up new comparisons between formations. Reassembling the complex, socially embedded wholes from a set of building blocks, then, does not guarantee a return to the old labels and categorizations with which we originally set out. (ibid., p. 162)

In Asprem's theory the vertical integration between lower and higher levels of ontology ought to be consistent and allow for explanatory pluralism according to the level of analysis (e.g., historical) without contradicting analysis on other levels (e.g., biological). At the same time the comparison taking place through a horizontal integration should enable intellectual exchange with neighboring disciplines (e.g., intellectual history, history of science, art history) working on the same or on similar levels of resolution but focusing on different aspects on a shared continuum (Asprem, 2016, p. 179).

In contrast to the previous definitional progression spanning from Faivre to Hanegraaff and to Bergunder, Asprem's approach is acutely aware of the tension between the creative power of epistemology (i.e., discourse producing reality) and the forceful creativity of ontology (i.e., materiality showing itself to be real). Asprem does not buy into any posits either promising direct access to the "essence" of esotericism or constructing a taxonomic scaffold from contingently available sources (2016, pp. 158-159). Nor does he ignore the world outside of discourse as an ontologically lower (i.e., developmentally foundational) level with human culture supervening on the evolutionary antecedent material and the embodied properties of the building blocks 
that light up in the ontologically higher (i.e., developmentally succeeding) level of discursive interaction, where the meaning of esotericism is negotiated (ibid., p. 161). Instead, Asprem argues for a reconstruction of the cognitive building blocks (e.g., universal cognitive dispositions), which are not identical to the docking discourse (e.g., esotericism), but will nevertheless inform the researcher about the relationship between the extra- and intra-discursive processes.

To rephrase this development with a more formal focus on the subject of esotericism: a thesis of ontological access ("we know esotericism to be x"/"we know esotericism to be constituted by x, y, z") (Faivre, 1994; Hanegraaff, 2012), has been countered by its antithesis of epistemological limitation ("we can only ever know 'esotericism' to be interpreted as x, y, z") (Bergunder, 2010), whereupon both have been sublated in the hierarchical system of the building blocks approach ("whatever the interpretation of the signifier 'esotericism,' we can scale it down to the point where we can know its constituent components and reassemble it from there") (Asprem, 2016).

Despite the apparent elegance of the definitional progression with an encompassing theoretical framework at its presumed synthesis of ontological and epistemological deliberations, the issue of interpreting esotericism-indeed, the issue of interpretation as such-is more complicated. Once we take a closer look at the basic axioms underlying each and every interpretational endeavor, an uncomfortable paradox makes itself felt, which will henceforth be referred to as the antinomy of interpretation. As we shall see in a moment, this incompatibility between two self-sufficient principles—already indicated in the juxtaposition of essentialist vs. discursive approaches, with Hanegraaff's narrativizing approach uncomfortably aiming in both directions-cannot be resolved through a dialectic argument (i.e., by combining "constructionist" and "naturalistic" analyses within a hierarchical framework) (Asprem, 2016, p. 162), since such synthesizing attempts reproduce the very binary which they set out to overcome. Instead, the conundrum at hand must be understood philosophically in order to be dealt with on a practical level, where radically divergent interpretations-e.g., of esotericism - will have to be acknowledged side by side as contributions to an eclectic understanding of our scholarly subject that cannot possibly be regarded as a "whole" because there is no unifying interpretation, but only conflicting accounts that can nevertheless be understood as philosophically necessary juxtapositions. 
Broadly speaking, the essentialist approach to esotericism relies on the scholar's relatively unconstrained interpretation (i.e., our epistemology) of available sources, in which historical entities manifest, entering discourse from a non-discourse outside (i.e., their ontology), while the discursive approach claims that interpretation of esotericism (i.e., its ontology) is thoroughly determined by contingent linguistic negotiations (i.e., our epistemology). Asprem's building blocks approach, in turn, attempts to combine both interpretational directions. On the one hand, it implies that discourses generate and sediment the meaning of esotericism (ontology) by dint of their persuasive gravitation (epistemology). On the other hand, it claims to retrieve the cognitive foundations (ontology) of practices, which are discursively linked to esotericism, employing the empirical inquiry of the cognitive science of religion (epistemology).

What we see here are two basic directionalities of interpretation, which I will refer to as vectors. ${ }^{5}$ In the first case, esotericism is excavated and carved out from time and space (i.e., from different moments, geographical locations and social contexts in history leading up to the present) in which "it" exists in the form of potent narratives, materialities, and practices that present themselves to the interpreter. This vector will be referred to as onto-epistemological, since in this directionality of interpretation the ontology of esotericism informs the interpreter's epistemology. For instance, we can observe the ontoepistemological vector in Faivre's understanding of esotericism as "a form of thought, the nature of which we have to try and capture on the basis of the currents which exemplify it" (Faivre, 1994, p. 4). Despite the necessity of the scholar to actively look into the sources "containing" esotericism, esotericism itself is presupposed (contrary to Faivre's own claim) as an entity, which makes itself noticeable through its manifestation in sources. In the second case, esotericism is generated throughout history, where linguistic (re-)negotiations attribute themselves to it. Regardless of the scholar's invested circumspection, whatever will eventually appear on the radar, will be a construct of the applied search filter. This vector will be referred to as epistemo-ontological, since the interpreter's epistemology of esotericism informs its ontology. For instance, we can observe the epistemo-ontological vector in Bergunder's understanding of esotericism as a "general term of identification" (2010, p. 26), which Bergunder regards as a "contingent nodal point or rather as the fixing of a contentious power discourse" (ibid., p. 26) in need of historicization.

5 For the purposes of this chapter, the usage of the term "vector" is limited to the directionality in the space of interpretation and does not claim any mathematical implementation, although a further development based on set theory appears to be a feasible endeavor. 
The Antinomy of Interpretation

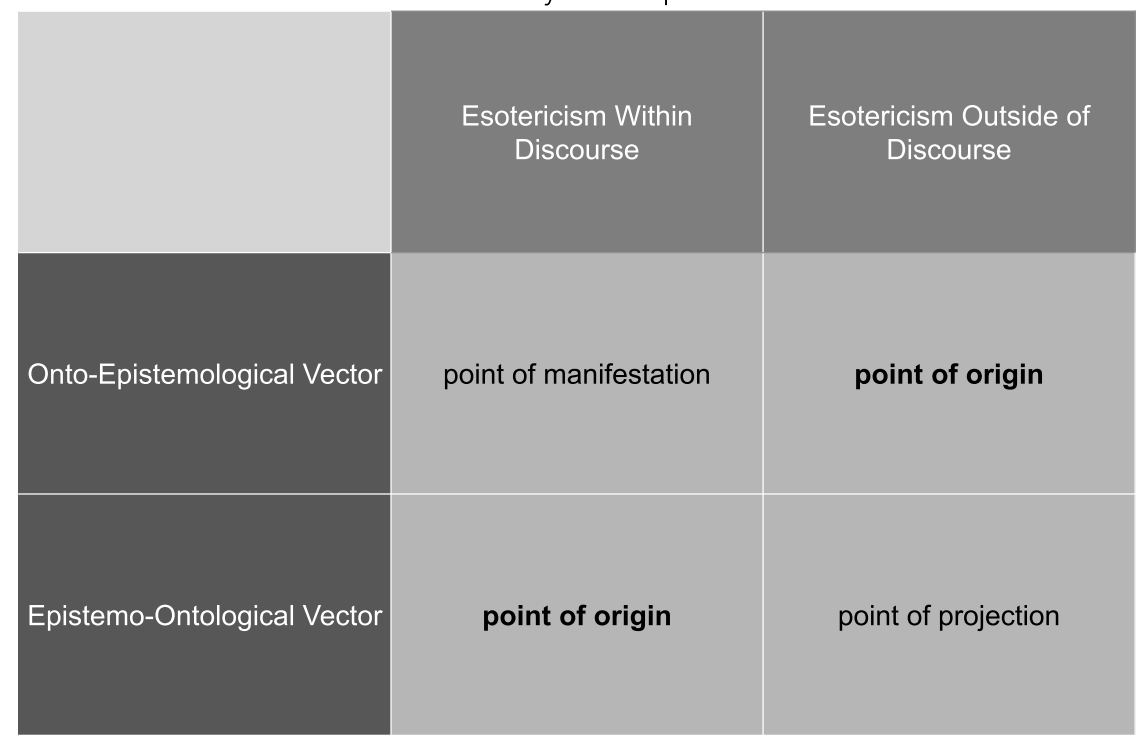

SCHEMATIC 1

In sum, this means that the onto-epistemological vector of interpretation allows us to see esotericism as an extra-discursive entity, manifesting within discourse while the epistemo-ontological vector of interpretation allows us to see esotericism as a discursive formation being projected to an assumed outside of discourse (schematic 1 ).

The inherent antinomy between the two vectors of interpretation and its consequences for the study of esotericism becomes evident once we closely examine the outlined definitional progression and spell out some of the intrinsic philosophical consequences for the various approaches to the study of esotericism. Bergunder's initial point of criticism was directed at the essentialist approach, which operates via the onto-epistemological vector and performs a readout of the available data on esotericism-i.e., ascertaining that esotericism is gnosis, theosophy, secrecy, or maintaining that it does gravitate around the themes of philosophy, science, and religion (Faivre, 1994). We can now interpret Bergunder's intervention as an application of the epistemo-ontological vector, which suggests that an ostensible readout of data-i.e., gnosis, theosophy, secrecy-is a socially negotiated projection to an assumed discursive outside, not a manifestation of an outside within discourse. The negation of this extra-discursive potentiality is identical with the negation of the onto-epistemological vector, which promises precisely the type of access - i.e., an understanding what esotericism "is" outside of its fluc- 
tuating social construction-which Bergunder's approach renders impossible. While Faivre and Bergunder can be allocated to one specific interpretational directionality, Hanegraaff's narrativizing approach seems to represent an intermediate step between Faivre and Bergunder, displaying the incommensurability between both directionalities of interpretation. Attempting to ride both vectors simultaneously, Hanegraaff suggests that esotericism is a narrative (epistemo-ontology), while also implying that the sources debating philosophy, theology/rationality, revelation can inform the scholar about the nature of esotericism (onto-epistemology) (Hanegraaff, 2012, pp. 6-7; Hanegraaff, 2013, p. 255). Asprem's building blocks approach, making use of the cognitive study of religion as a gateway to studying esotericism, is then the attempt to consciously work with both vectors by allocating them to different operational spheres. This synthesizing attempt is visible in Asprem's (2016) lower and higher levels of analysis-e.g., the biology of religious experience/the cultural construction of religious experience-which are integrated through the vertical (i.e., hierarchical) and horizontal (i.e., interdisciplinary) axes.

The crucial problem with the entire definitional progression in the study of esotericism - and, in fact, with any comparable definitional progression - is the varying inability to address and clarify the basic axioms of interpretation, which are directly linked to the two interpretative directionalities. The relationship between the onto-epistemological and the epistemo-ontological vectors can be clarified through four propositions, the first two of which describe the antinomy of interpretation:

- Proposition 1: If esotericism exists as a self-sufficient entity outside of discourse manifesting within discourse (e.g., the neural structures of the human brain generating communicable perceptions of non-material worlds), ${ }^{6}$ then its contingent (i.e., culturally negotiated) interpretations will not affect its essential extradiscursive features (e.g., the impact of neurotransmitters on the perception of non-material worlds).

- Proposition 2: If esotericism exists within discourse (i.e., as culturally negotiated interpretations concerning experiences of non-material worlds) and is merely being projected onto a presumed outside of discourse (e.g., attributing contingent meaning to neurotransmitters), this outside will have no say whatsoever in what esotericism is within discourse and will therefore have no meaning pertaining to the study of esotericism.

6 Note that evolutionary theory is only one possible element of many onto-epistemological interpretations, since the different theories are defined by the vectors, not vice versa. 
These propositions, which correspond with the onto-epistemological and the epistemo-ontological vectors, are incommensurable. We can either accept that the outside of discourse determines the inside of discourse or maintain that the inside of discourse determines the outside of discourse-both cases can be plausibly argued and have engaged philosophical thinking throughout the centuries as well as the present (Meillassoux, 2008).

To be clear, the argument here is not that either interpretational directionality is correct or mistaken; rather we cannot use both vectors in the same interpretive act. If we interpret esotericism onto-epistemologically (e.g., as hardwired predispositions to see supernatural beings), it will manifest in discourse as esotericism no matter what signifiers (e.g., "gnosis," "theosophy," "secrecy," "occultism," "Hermeticism") discourse uses for the signified. If we interpret esotericism epistemo-ontologically (e.g., the vision of supernatural beings as a historically contested ascription to evolutionary mechanisms), the signified will not tell us anything about itself, because we are assuming it to be the contingent product of discourse.

The antinomy of interpretation is perhaps most plainly visible in Asprem's attempt of synthesizing both vectors. Asprem relies on an evolutionary paradigm (i.e., on the onto-epistemological vector) within which human biology (i.e., onto-epistemological) and culture (i.e., epistemo-ontological) are hierarchically connected (Asprem, 2016, pp. 16o-161). The trouble with this hierarchy, however, consists in the intrinsic function of the epistemo-ontological vector to call into question the very existence of an evolutionary process as an extradiscursive reality. As Asprem himself writes with regards to the building blocks: they are conceptual tools that help us see how complex composites might work—not a route to "foundations," "essences," or "rock bottom" (2016, p. 161).

But if this were to be the case, we would have to find a reason to choose one conceptual tool over another. The mere speculation as to how "composites might work" flows in the direction of the epistemo-ontological vector, the onto-epistemological vector cannot but lead the interpreter to ' foundations,' 'essences,' or 'rock bottom.' Logically speaking, then, Asprem has no choice but to consolidate his theory onto-epistemologically, since a thorough consideration of the epistemo-ontological vector would suggest that evolution itself is but $a$ contingent theory, projecting itself to an outside of discourse, which, in turn, would be unable to manifest on the inside.

This observation suggests that approaches operating with one or the other vector can function well for themselves but will inevitably lead to contradictions if confronted with each other, as has been demonstrated up to this point. 
So far, two points have been argued. First, the two vectors of interpretationi.e., onto-epistemological and epistemo-ontological—have been derived from the definitional progression in the study of esotericism. Second, their incommensurable character has been discussed as the antinomy of interpretation. And yet, it remains far from obvious, in what sense these vectors exist in the first place and how their incommensurability can be squared with their individually meaningful performance. After all, interpreting esotericism as a sedimented societal ascription appears equally plausible to interpreting it as a discourse emerging from the potentiality of the human nervous system. There is ample evidence for the hegemonic character of meaning negotiations, taking place throughout human history and retroactively portraying themselves as inevitable and "natural" (Butler, 1993). Put more formally, the very act of interpretation requires the projection of a signified by the interpreter onto a signifier, since the signified is attributed to a signifier by an interpreter (i.e., we make the connection between our research in neuroscience and the esoteric narratives, materialities, and practices of our research subjects). However, an equally plausible case can be made for the unfolding of esoteric narratives, materialities, and practices as a consequence of the biopsycho-social mechanics we refer to as "human culture" (Boyer, 2001). Put more formally, we have to "take" the signified from the signifier, precisely because it is "given" (e.g., the religious experience of individuals offers an understanding of itself through research in neuroscience done by the interpreter). Once the respective epistemo-ontological and onto-epistemological presuppositions (i.e., contingent semantics/evolutionary constraints) are accepted, univectoral interpretation delivers sensible information about our subject of study (e.g., esotericism as a projection of discourse vs. esotericism as a manifestation of the human psyche) while excluding the reverse directionality.

A clarification of both unanswered questions (in what sense do the vectors exist and how can their incommensurability be squared with their individual functioning) can be provided by what will be referred to as the principle of bivectoral necessity, described in the third and fourth proposition pertaining to the basic axioms of interpretation. Assuming the existence of an interpreter and an interpreted, two incommensurable functions of interpretation will take place:

- Proposition 3: Something will be interpreted via a signified which emerges from a signifier (e.g., practices directed at the knowledge-acquisition of non-material worlds show themselves to the interpreter as such). 
- Proposition 4: The interpreter will interpret something by attributing a signifier with a signified (e.g., the interpreter projects "esotericism" onto a set of practices directed at the knowledge-acquisition of non-material worlds). As should be evident by now, both propositions correspond with the ontoepistemological and the epistemo-ontological vectors and are therefore incommensurable. However, they are simultaneously logically necessary in themselves as unifocal directionalities, since they and only they make interpretation possible. We can make sense of the principle of bivectoral necessity by imagining the situation through the metaphorical use of Schroedinger's famous cat, which is presumed to be simultaneously dead and alive in its box (due to an installed mechanism, killing the cat with a $50 \%$ probability) until the box is opened and the cat is observed (Gribbin, 1984). Let us presume that we want to know what a cat is, never having seen one and only being informed that a cat is in the box. Once interpretation takes place, we will have one and only one of two and only two possible outcomes. The repetition of the experiment will bring about an even distribution of two outcomes, helping us to arrive at the conclusion that the cat exists in two states. These two states, however, will have no middle ground between them, there will be no continuum connecting the living and dead cat - the interpretations will be literally incommensurable but equally necessary, in order to arrive at a description of what is interpreted.

Put together, the underlying logic for the principle of bivectoral necessity-i.e., the necessity of onto-epistemological and epistemo-ontological directionalities of interpretation-and the antinomy of interpretation-i.e., the incommensurability of the two fundamental interpretational directionalities - constitute a set of counterintuitive, yet indispensable assumptions. It might, in fact, be possible to explain both principles semiotically by borrowing from and significantly adapting Ernesto Laclau's theory of signification (Laclau, 2005), which was used by Bergunder as the basis for his exclusively epistemo-ontological approach (Bergunder, 2010). In this re-interpretation of Laclau, ${ }^{7}$ the semiotic logic of equivalence states that signifier and signified share common (i.e., equivalential) ground, since they would otherwise not be understandable as two distinct, yet connected elements in a shared context (e.g., the materiality from which neurotransmitters and experiential narratives of non-material worlds emerge as causally connected entities). Ontoepistemologically speaking, the evolved materiality of neurotransmitters is the signified which manifests in the signifier of experiential narratives of nonmaterial worlds. This implies that the onto-epistemological directionality of

7 For a concise understanding of Laclau's epistemo-ontological semiotics, cf. Laclau, 2005 . 
interpretation takes the equivalence between the seemingly different signified (molecular structures) and signifier (language) to be their point of origin rather than the result of a projection (i.e., neurotransmitters and experiential narratives of non-material worlds originate from a common evolved material foundation with neurotransmitters at the lower level and experiential narratives at the upper level).

The logics of difference states that the signifier and the signified are not identical, since they would otherwise not be understandable in a shared context as two connected, yet distinct (i.e., differential) elements (e.g., experiential narratives of non-material worlds and neurotransmitters are linked through discourse). Epistemo-ontologically speaking, neurotransmitters are the signifier while experiential narratives of non-material worlds would be the signified being impressed into the signifier. This implies that the epistemo-ontological directionality of interpretation takes the equivalential context of differing elements to be the result of a projection rather than the point of origin. From this we can deduce that the onto-epistemological vector is operating on the assumption that equivalence manifests differential elements, which are nevertheless causally linked to the lower level, while the epistemo-ontological vector is operating on the assumption that differential elements are projected into equivalence, reversing the causality.

What this all means in more prosaic terms is this: the onto-epistemological vector is active when equivalence bifurcates into difference (neurotransmitters and experiential narratives of non-material worlds) by dint of its own potentiality (e.g., evolved materiality). The epistemo-ontological vector is active when difference (e.g., neurotransmitters and experiential narratives of non-material worlds) contracts to equivalence (e.g., materiality) through a discursive intervention (schematic 2). ${ }^{8}$ But what is it that happens before interpretation takes place? The answer, which brings back the analogous use of Schroedinger's cat, is that we cannot possibly know, because it is only when interpretation takes place that we have access to whatever is interpreted. A possible speculation would be to think of the pre-interpreted state as a superposition of signifier and signified in a state of pure potential, leaping from their superposition to the respective starting and ending points of the two vectors, once interpretation takes place and the logics of difference and equiv-

8 Framed in this way, the mind/matter dichotomy can be seen as the ultimate polarity at the respective starting and ending points of the onto-epistemological and epistemo-ontological vectors. Stretching this line of thought even further, matter and mind could be regarded as the impossible, yet necessary complements of Being that emerge in each and every act of interpretation. 
The Principle of Bivectoral Necessity

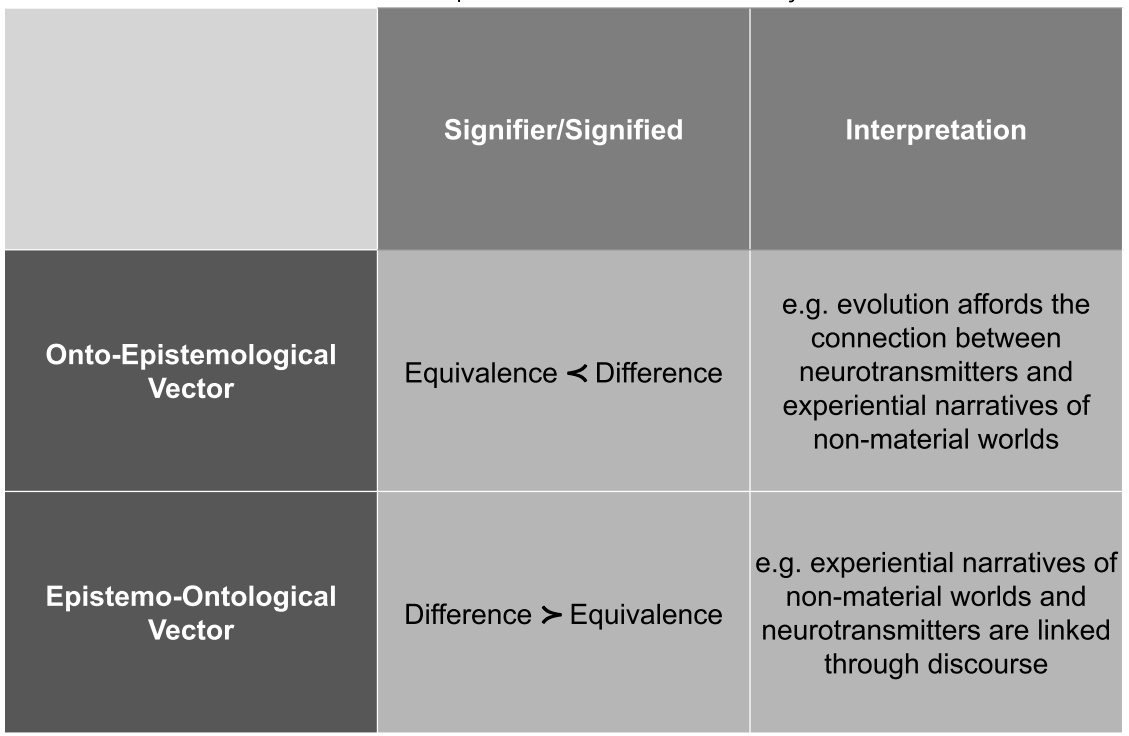

SCHEMATIC 2

alence take over. What we can say with more certainty, however, is how to bring about the two possible states of interpretation, since we are able to consciously employ the onto-epistemological and epistemo-ontological vectors. This implies that all interpretable entities (again, there is little we can say about uninterpreted entities) can be forced to show themselves through their onto-epistemological and epistemo-ontological components, resulting in incommensurable yet necessarily correct interpretations that cannot be synthesized but must be acknowledged as equally sensible.

\section{The Varifocal Theory of Interpretation}

If we accept the antinomy of interpretation, which has been rendered plausible through the principle of bivectoral necessity, we must ask ourselves two questions: first, why should the study of esotericism — or the study of any subject for that matter-not simply proceed with its already existing approaches? Second, how can our insight into the opposed directionalities of interpretation contribute to an alternative take on the object of inquiry, integrating elements from the definitional progression in the study of esotericism?

To tackle the first question: if it is indeed the case that two and only two directionalities of interpretation exist and can be applied to esotericism and 
that they are antinomic as well as necessary, using only one vector of interpretation by definition neglects information offered by the other vector. We have seen, however, that the unconscious oscillation between both vectors will lead to intractable contradictions. This was the case with Faivre, who first claimed that there was no such thing as "esotericism in itself" (epistemoontologically) before arguing the opposite by suggesting that esotericism had indeed a nature showing through the study of the source material (implying an onto-epistemological vector) (Faivre, 1994, p. 4). This was the case with Hanegraaff, who started out with the assumption that esotericism emerged as a narrative about ancient wisdom, while simultaneously suggesting that his sources could inform him about esotericism (2012, pp. 6-7; 2013, p. 255). This was the case with Bergunder, who approached esotericism as a negotiated term of identification (epistemo-ontological) without however, granting the same critical privilege to his theoretical toolset consisting of terms such as "discourse," "empty signifier," and "power," which, in turn, appeared to be the foundation of reality (implying an onto-epistemological vector) (2010, p. 26).

In contrast to the aforementioned approaches, Asprem (2016) attempts to consciously work with both vectors by incorporating "naturalistic" and "constructionist" methods. In this way, he aims to integrate research on esotericism along a vertical as well as a horizontal axis and allow for the coexistence of similar as well as dissimilar research paradigms on the continuum of the scientific and scholarly disciplines. However, Asprem's approach reaches an insurmountable obstacle with the antinomy of interpretation, which re-inscribes itself into Asprem's integrative endeavor, once the epistemo-ontological vector is activated: while the horizontal axis allows for the coexistence of univectoral approaches (e.g., intellectual history, history of science, art history/medicine, neuroscience, psychology), the vertical axis promises a hierarchical integration of onto-epistemological and epistemo-ontological interpretations, a promise it can only deliver by subordinating one vector under another (i.e., epistemo-ontological under onto-epistemological). The repressed antinomy of interpretation returns forcefully due to the principle of bivectoral necessity, once the underlying evolutionary theory, which is the indispensable onto-epistemological foundation for the building blocks approach, is analyzed epistemo-ontologically and deciphered as a contingent product of negotiations for interpretative hegemony, masking itself as self-evidently objective (Hull, 2005). To fully answer the first question: we should not simply proceed with the already existing approaches to esotericism, because none of them are capable of dealing with the antinomy of interpretation and the principle of bivectoral necessity, which, in turn, are able to explain the contradictions of interpretation. 
This reflection allows us to tackle the second question: if it is indeed the case that two and only two directionalities of interpretation exist and can be applied to esotericism and that they are antinomic as well as necessary, we ought to accomplish, not a linear hierarchical, but an oscillatory side-by-side integration of both vectors in order to acquire the fullest possible interpretation of our subject. This excludes the option of using only one vector, but also disables us from trying to subordinate both vectors in one interpretive approach because the other vector will inevitably "cannibalize" our interpretive foundation, either because we produce contradictions (e.g., Faivre, Hanegraaff, Bergunder), or because we realize that no matter how sophisticated our theory, contradictions remain unresolved (e.g., Asprem). The only remaining option, then, is not to synthesize the vectors, while allowing numerous interpretations to flow both ways. What is interpreted in this fashion will invariably be eclectic, since adding the interpretations available through the onto-epistemological and the epistemo-ontological vectors will result in separate but complementary interpretations, which cannot be summed up but must be understood as equally valid contributions to an eclectic totality. As with Schroedinger's cat, which can be dead or alive without any intermediate state, esotericism will be interpreted as onto-epistemological or epistemo-ontological. What this rather uncomfortable suggestion implies is that our interpretations of esotericism (e.g., esotericism as the result of evolutionary processes vs. the evolutionary predisposition to sense superhuman entities as a discursive fixation) will have to stand next to each other on truly equal footing without merging into one single explanatory framework.

What can act as an encompassing theoretical structure, explaining, not what esotericism is, but why it will inevitably be interpreted through two vectors, is a theory of sensemaking emerging from the antinomy of interpretation and the principle of bivectoral necessity. This Varifocal Theory of Interpretation posits that an interpretation adequately showing the eclectic interpretive outcome of any given research subject (i.e., presenting through the onto-epistemological and the epistemo-ontological vector) needs to apply a set of varifocal (i.e., bifocal) lenses between which the interpreter will have to switch back and forth in order to gain an in-depth understanding of esotericism (schematic 3).

Since no single theory can simultaneously peak through both lens sections, the oscillatory employment of several approaches along the transdisciplinary spectrum between the natural sciences, the social sciences, and the humanities is in order, each of which have traditionally employed both vectors with a binary tendency (i.e., with the natural sciences often choosing the onto-epistemological route, the humanities regularly opting for the epistemoontological route and the social sciences employing one or the other, depend- 


\section{Varifocal Interpretation}
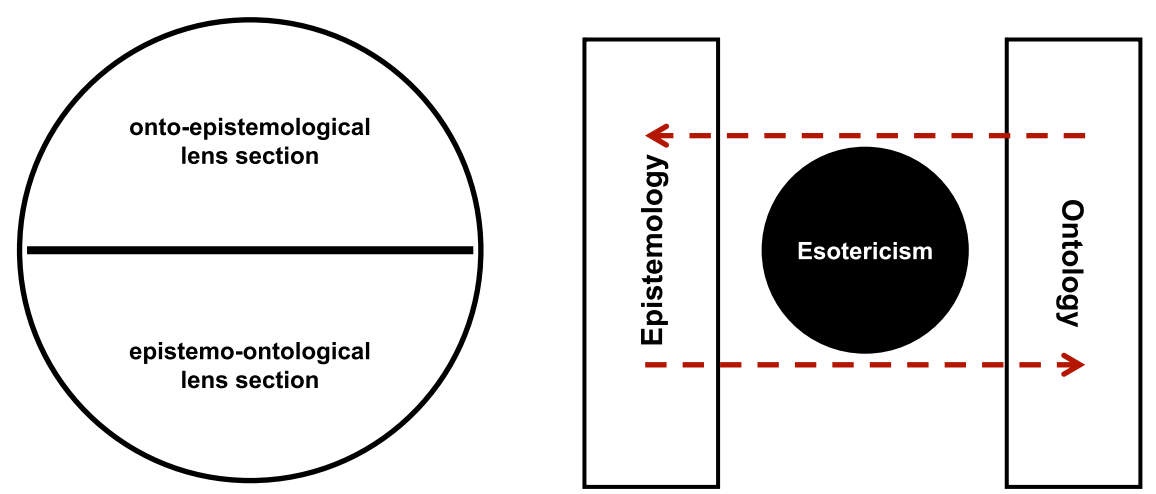

SCHEMATIC 3

ing on their inclination towards semantic or mathematical models). In direct contrast to the usage of different approaches found in the definitional progression in the study of esotericism, this endeavor has to be constantly and consistently aware of the antinomy of interpretation and the principle of bivectoral necessity.

A varifocal interpretation of esotericism will therefore proceed by continuously alternating between both vectors. On the one hand, Asprem's leaning towards an evolutionary perspective as the foundation for human perception could function as a starting point and theoretical umbrella for neighboring theories that operate exclusively through the onto-epistemological analysis of esotericism. The lower-level components structuring onto-epistemological interpretation could then be thoroughly analyzed as

relatively simple and stable concepts that are grounded in evolved mental architecture and embodied interactions with the environment. Examples include the bodily based, domain-general schemata studied by cognitive linguistics (e.g., part-whole, path, CONTAINMENT) and concepts such as ACTION, CAUSE, INTENTION, or EVENT that are presumably grounded in evolved, domain-specific learning systems and hence recognizable across cultures. (Asprem, 2016, pp. 16o-161)

From this point onwards, an onto-epistemological analysis could fully embrace the intravectoral spectrum of disciplines, analyzing esotericism as a bio-psycho-socially evolved set of narratives, materialities, and practices. Var- 
ious (sub)disciplines based on the premises of evolutionary theory and the methods of inferential statistics - sociobiology, evolutionary psychology, neuroscience, psycholinguistics, etc.-could then make their contributions as to why, when, where, and how esotericism has emerged in the complex interactions between human individuals, collectives, and institutions (Downes, 2011; Grinde, 1998; McNamara, 2009).

On the other hand, Bergunder's discursive approach could function as a starting point and theoretical umbrella for neighboring theories which operate exclusively through the epistemo-ontological study of esotericism. The negotiatory practices gravitating around the signifier "esotericism" could then be thoroughly analyzed on the intravectoral spectrum. Epistemo-ontologically operating concepts from (sub)disciplines such as the study of religion, sociology, cultural theory, semiotics etc. could augment and enlarge the notion of esotericism as an empty signifier prone to contingent fixations (Barker, 2001; Bourdieu, 1993; Chandler, 2017; Wijsen, 2013). Bergunder himself has introduced an additional theoretical tool, arguing for Pierre Bourdieu's sociological concept of the field, which suggests a differentiation of articulatory discursive spaces and could help to situate esotericism within a variety of intersecting societal fields (Bourdieu, 1993):

Thus, there are academic, journalistic, literary, religious and political fields of discourse etc., which can be differentiated [...]..$^{9}$ Applying this to esotericism, it could be said that the reproduction of esotericism's empty signifier takes place through the articulation of a discursive community in different discourse fields. Esotericism as an identity positioning has its place in a religious discourse field. However, the articulation of equivalence chains and their reproduction takes place also in other discourse fields. [...] [A]cademics can be esotericists or journalists can be anti-esotericists etc. (Bergunder, 2010, p. 25)

While Bergunder is clearly limiting his approach epistemo-ontologically, Asprem's attempt to synthesize both vectors is subdued by the antinomy of interpretation, leading Asprem to privilege the onto-epistemological vector due to his hierarchical subordination of discourse to the evolved materiality of

9 Note how Bergunder rhetorically inhibits even the possibility of an onto-epistemological vector in the missed-out lines: "Surely nothing can be said against this proposal, so long as the field concept does not contain any hidden category of order that exhibit an outer discursive reference. Fields of discourse must themselves emerge in the discursive articulation" (2010, p. 25). 
human cognition. It might, however, be possible to reformulate the building blocks approach as varifocal in order to avoid the philosophical conundrum at hand. If Asprem should choose to adopt the Varifocal Theory of Interpretation, he would have to resist the temptation to generate a hierarchical connection of the two vectors, instead, accepting the principle of bivectoral necessity and letting both vectors oscillate with their interpretational directionalities untouched by each other.

\section{$5 \quad$ In Sum}

This chapter has made the point that the definitional progression in the study of esotericism from Faivre to Hanegraaff to Bergunder and to Aspremdespite resembling a dialectical movement-has ultimately been unable to bring about a theoretical clarification and synthesis of interpretive approaches to esotericism. This conundrum was explained through the antinomy of interpretation (schematic 1) and the principle of bivectoral necessity (schematic 2) as the two elements governing each and every interpretational enterprise. As a counterproposal, a varifocal understanding of esotericism has been suggested, oscillating between the onto-epistemological and the epistemoontological vectors without attempting to generate a hierarchy between the two interpretational directionalities. This move allows us to access the always eclectic interpretational outcome predicted by the antinomy of interpretation (schematic 3). ${ }^{10}$ Moreover, the principle of bivectoral necessity explains whydespite our inability to synthesize the onto-epistemological and the epistemoontological vectors-we cannot but employ both interpretative directionalities, even though our usage should be careful not to subsume one approach under the other in order to avoid the contradictions running through the definitional progression in the study of esotericism as well as the entire history of interpretation itself.

10 To quickly counter the possible allegation of promoting a reactionary return to some 'long overcome' cartesian dichotomy: arguing that the onto-epistemological and the epistemoontological vectors are incommensurable does indeed block a merged interpretative access to esotericism as a materially potent entity and esotericism as a discursively inscribed notion. Although this concept is arguably hard to take and in need of further philosophical explanation and empirical application, I have attempted to demonstrate its logical structure and empirically observability, shining a new light on the longstanding conflict between academic disciplines spread between the two vectors. Cf. Ashman and Barringer, 2001. 
What, then, would a discipline or academic field admitting to the Varifocal Theory of Interpretation look like? Needless to say, the varifocal approach is not limited to any subject of interest, since the general presuppositions of the onto-epistemological and epistemo-ontological vectors apply for the process of interpretation itself. However, disciplines used to operate with one vector or the other would have to significantly expand their theoretical and methodological scope in order to conduct varifocal analysis. This is why Bergunder's sole focus on the poststructuralist tradition with its epistemo-ontological interpretations cannot be employed towards a varifocal analysis, while Asprem's usage of the cognitive science of religion in addition to discourse theory (or vice versa!) can be reformulated as a varifocal analysis of esotericism.

The ultimate benefit of the Varifocal Theory of Interpretation lies not in a grand unifying system, but in rejecting the impossible unification of incommensurable directionalities, which are nevertheless equally accepted. Although this might seem to be a rather dull suggestion in light of the theoretical effort which has been employed to arrive at this conclusion, the implications are far from trivial. Academic disciplines with the Varifocal Theory of Interpretation at their heart would be relieved from the burden to persistently partake in shadowboxing with opposing academic viewpoints (if the opposition is due to the antinomy of interpretation). They could, instead, focus on the full scope and abundance of both interpretational directionalities. This might also have a significant effect on highly politicized subjects of interpretation. After all, poststructuralist deconstruction has been used to constantly question the legitimacy of scientific findings (e.g., the onto-epistemological interpretation of sex and gender as essentially binary) while the reduction of human behavior to evolved material constraints has continued to dismiss the legitimacy of individually queering identity-articulations (e.g., gender and sex as purely performative acts) (Ashman and Barringer, 2001). Allowing for both interpretive directionalities would imply an acceptance of this fundamental paradox, which we cannot dissolve, no matter how convincing our univectoral arguments might be. It would force us out of the echo-chambers created around our favorite interpretational route and compel us to acknowledge, rather than ignore, suppress, or fight the opposing avenue. It would enable us to fully appreciate the scope and depth of scientific and scholarly understanding tilting to one vector or the other, without constantly attempting to subvert incommensurable interpretations. This oscillating movement between the two vectors rightly feels like the alternation between two entirely different worlds. These worlds, however, are all we have in interpretation. It is therefore our choice to remain partial foreigners or become questing commuters. 


\section{Bibliography}

Ashman, K.M.B. and Barringer, P. (eds.) (2001) After the Science Wars. London and New York: Routledge.

Asprem, E. (2016) “Reverse-Engineering 'Esotericism': How to Prepare a Complex Cultural Concept for the Cognitive Science of Religion," Religion, 46, pp. 158-185.

Barker, C. and Dariusz, D. (2001) Cultural Studies and Discourse Analysis: A Dialogue on Language and Identity. London: SAG E.

Bergunder, M. (2010) "What is Esotericism? Cultural Studies Approaches and the Problems of Definition in Religious Studies," Method and Theory in the Study of Religion, 22, pp. 9-36.

Bourdieu, P. (1993) The Field of Cultural Production. New York: Columbia University Press.

Boyer, P. (2001) Religion Explained: The Evolutionary Origins of Religious Thought. New York: Basic Books.

Butler, J. (1993) Bodies that Matter: On the Discursive Limits of "Sex." New York and London: Routledge.

Chandler, D. (2017) Semiotics: The Basics. London and New York: Routledge.

Downes, W. (2011) Language and Religion: A Journey into the Human Mind. Cambridge: Cambridge University Press.

Faivre, A. (1994) Access to Western Esotericism. New York: State University of New York Press.

Foucault, M. (1977) “Nietzsche, Genealogy, History," in Bouchard, D.F. (ed.) Language, Counter-Memory, Practice. Ithaca: Cornell University Press.

Gribbin, J. (1984) In Search of Schrödinger's Cat. Toronto: Bantam Books.

Grinde, B. (1998) “The Biology of Religion: A Darwinian Gospel," Journal of Social and Evolutionary Systems, 21, pp. 19-28.

Hanegraaff, W.J. (2012) Esotericism and the Academy: Rejected Knowledge in Western Culture. Cambridge: Cambridge University Press.

Hanegraaff, W.J. (2013) "The Power of Ideas: Esotericism, Historicism, and the Limits of Discourse," Religion, 43, pp. 252-273.

Hull, D.L. (2005) “Deconstructing Darwin: Evolutionary Theory in Context," Journal of the History of Biology, 38, pp. 137-152.

King, R. (1999) Orientalism and Religion: Postcolonial Theory, India and "the Mystic East." London and New York: Routledge.

Kuhn, T.S. (1962) The Structure of Scientific Revolutions. Chicago and London: University of Chicago Press.

Laclau, E. (2005) On Populist Reason. London and New York: Verso. 
Masuzawa, T. (2005) The Invention of World Religions: Or, How European Universalism Was Preserved in the Language of Pluralism. Chicago and London: The University of Chicago Press.

McCutcheon, R.T. (1997) Manufacturing Religion: The Discourse on Sui Generis Religion and the Politics of Nostalgia. New York and Oxford: Oxford University Press.

McNamara, P. (2009) The Neuroscience of Religious Experience. Cambridge: Cambridge University Press.

Meillassoux, Q. (2008) After Finitude. London and New York: Continuum.

Strube, J. (2021) "Towards the Study of Esotericism without the 'Western": Esotericism from the Perspective of a Global Religious History," in Asprem, E. and Strube, J. (eds.) New Approaches to the Study of Esotericism. Leiden and Boston: Brill, pp. $45^{-66 .}$

Wijsen, F. (2013) “Editorial: Discourse analysis in religious studies," Religion, 43, pp. 1-3. 